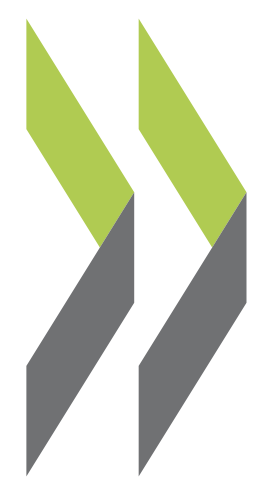

OECD Economics Department Working Papers No. 1222

What Impedes Household Investment in Energy Efficiency and Renewable

Nadia Ameli, Nicola Brandt

\title{
Energy?
}


Organisation de Coopération et de Développement Économiques

Organisation for Economic Co-operation and Development

21-May-2015

ECONOMICS DEPARTMENT

English - Or. English

\section{WHAT IMPEDES HOUSEHOLD INVESTMENT IN ENERGY EFFICIENCY AND RENEWABLE ENERGY?}

ECONOMICS DEPARTMENT WORKING PAPERS No. 1222

Nadia Ameli and Nicola Brandt

OECD Working Papers should not be reported as representing the official views of the OECD or of its member countries. The opinions expressed and arguments employed are those of the author(s).

Authorised for publication by Robert Ford, Deputy-Director, Country Studies Branch, Economics Department.

All Economics Department Working Papers are available at www.oecd.org/eco/workingpapers

JT03376817

Complete document available on OLIS in its original format

This document and any map included herein are without prejudice to the status of or sovereignty over any territory, to the delimitation of international frontiers and boundaries and to the name of any territory, city or area. 
OECD Working Papers should not be reported as representing the official views of the OECD or of its member countries. The opinions expressed and arguments employed are those of the author(s).

Working Papers describe preliminary results or research in progress by the author(s) and are published to stimulate discussion on a broad range of issues on which the OECD works.

Comments on Working Papers are welcomed, and may be sent to the Economics Department, OECD, 2 rue André-Pascal, 75775 Paris Cedex 16, France, or by e-mail to eco.contact@ oecd.org.

This document and any map included herein are without prejudice to the status of or sovereignty over any territory, to the delimitation of international frontiers and boundaries and to the name of any territory, city or area.

The statistical data for Israel are supplied by and under the responsibility of the relevant Israeli authorities. The use of such data by the OECD is without prejudice to the status of the Golan Heights, East Jerusalem and Israeli settlements in the West Bank under the terms of international law.

\section{(C) OECD (2015)}

You can copy, download or print OECD content for your own use, and you can include excerpts from OECD publications, databases and multimedia products in your own documents, presentations, blogs, websites and teaching materials, provided that suitable acknowledgment of OECD as source and copyright owner is given. All requests for commercial use and translation rights should be submitted to rights@oecd.org 
ECO/WKP(2015)40

\section{ABSTRACT/RESUMÉ \\ What Impedes Household Investment in Energy Efficiency and Renewable Energy?}

Energy efficiency and renewable energy technologies provide important opportunities to reduce greenhouse gas emissions. However, households fail to take up many clean energy investments that are cost-effective. This paper reviews different explanations for apparent underinvestment in energy efficiency that have been put forward in the literature. While investments in renewable energy technologies are typically not (yet) profitable, many of its drivers are similar to those that determine energy efficiency investments, and the two types of investment are therefore assessed jointly. The paper also provides new evidence regarding barriers to investment in energy efficiency based on the OECD Survey on Household Environmental Behaviour and Attitudes. Finally, policy solutions that would help overcome some of these barriers are also presented.

JEL Classification codes: Q38, Q41

Keywords: energy efficiency gap, market failures, behavioural failures

************************

\section{Quels sont les obstacles à l'investissement des ménages dans la rénovation énergétique et les énergies}

renouvelables?

La rénovation énergétique et les énergies renouvelables constituent un important moyen de réduire les émissions de gaz à effet de serre. Or, les ménages n'engagent pas un grand nombre d'investissements dans les énergies propres qui seraient rentables. Le présent document passe en revue différents arguments présentés dans les travaux publiés pour expliquer le sous-investissement constaté dans l'efficacité énergétique. Même si les investissements dans les technologies d'énergie renouvelable ne sont, généralement pas (encore) rentables, bon nombre de ses pilotes sont similaires à celles qui déterminent les investissements d'efficacité énergétique, et les deux types d'investissement sont donc évalués conjointement. Il présente aussi de nouveaux éléments sur les obstacles à l'investissement dans ce domaine, provenant de l'enquête de l'OCDE sur la politique de l'environnement et le comportement individuel. Enfin, il expose des solutions que les pouvoirs publics pourraient mettre en œuvre pour aider à surmonter certains de ces obstacles.

Classification JEL: Q38, Q41

Mots-clés: energy efficiency gap, les défaillances du marché, les défaillances comportementales 
TABLE OF CONTENTS

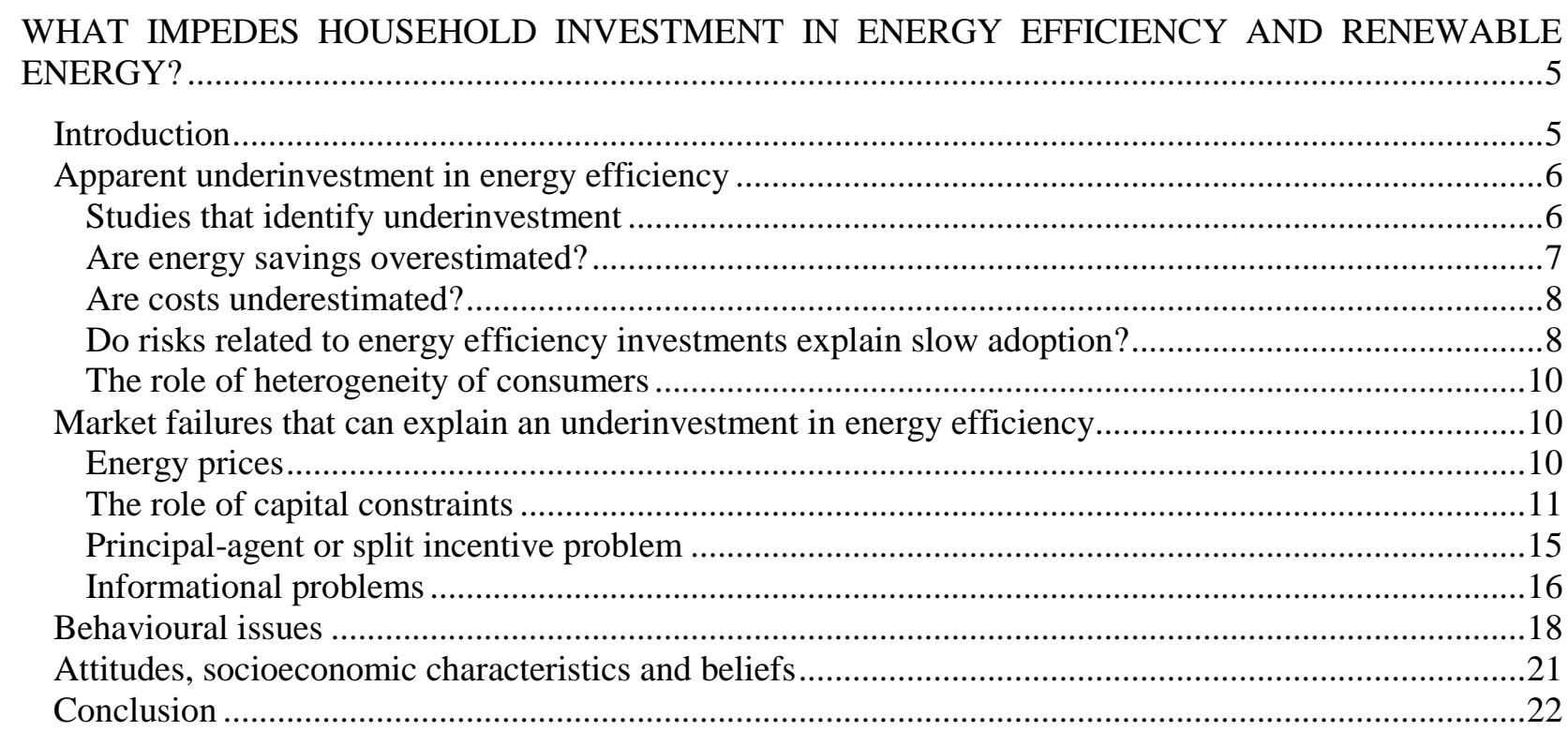

BIBLIOGRAPHY .24

Tables

1. Main barriers to energy investment and policy solutions .21

Figures

1. Changes in income and the predicted probability of investing in energy-efficient appliances. .14 
ECO/WKP(2015)40

\title{
WHAT IMPEDES HOUSEHOLD INVESTMENT IN ENERGY EFFICIENCY AND RENEWABLE ENERGY?
}

\author{
by \\ Nadia Ameli and Nicola Brandt ${ }^{1}$
}

\section{Introduction}

1. Investment in energy efficiency and renewable energy technologies are key to reduce greenhouse gas emissions. Global emissions have continued to grow by 44\% from 2000 to 2011 (IEA 2013) and policy action to reverse this trend is urgently needed. By adopting energy efficiency measures ${ }^{2}$, households can make an important contribution to limiting climate change. In most OECD countries, the building sector, a large part of which is residential, currently accounts for more than $40 \%$ of final energy consumption and of $\mathrm{CO}_{2}$ emissions (IEA 2012). Although countries have made some progress in setting energy standards and codes for new buildings, further improving the efficiency of energy use in the existing building stock will be essential to make rapid progress. Given its size compared to new buildings, the existing building stock is much more important for energy consumption and emissions. Energy consumption in the building sector is largely dominated by electricity and natural gas (Saheb et al., 2013), so a wider adoption of energy-efficient technologies would reduce fossil-fuel based energy use, cutting $\mathrm{CO}_{2}$ emissions.

2. Studies suggest that many energy efficiency measures for $\mathrm{CO}_{2}$ abatement in buildings are costeffective even at current energy prices that generally do not reflect the externalities associated with greenhouse gas emissions. By 2020 there is a potential to reduce the projected baseline emissions of residential and commercial buildings worldwide by approximately $29 \%$ with a positive economic return, according to the Intergovernmental Panel on Climate Change (IPCC 2014). The International Energy Agency (IEA) noted that the building sector achieves less than one-fifth of its abatement potential that would be profitable under current policies (IEA 2012). Other studies, as well, concluded that many economically profitable investments in energy efficiency are not adopted (Chandler et al., 2009).

3. There is an on-going debate on why consumers and businesses sometimes fail to adopt seemingly profitable energy-efficient products and practices.

4. This paper discusses different hypotheses explaining underinvestment in energy efficiency in developed countries that have been put forward in the literature. These include distortions in energy prices, credit constraints, principal-agent problems, informational failures and consumer behaviour that differs from the economic paradigm of rationality. This paradigm rests on the assumption that individuals have

1. Nadia Ameli and Nicola Brandt are members of the Economics Department of the OECD. The research leading to these results has received funding from the People Programme (Marie Curie Actions) of the European Union's Seventh Framework Programme (FP7/2007-2013) under REA grant agreement PIEFGA-2012-331154 - project PACE (Property Assessed Clean Energy). The authors would like to thank Virginie Marchal, Peter Hoeller, Daniel Kammen and various participants of OECD seminars for their valuable comments and suggestions and Veronica Humi for technical preparation.

2. Energy efficiency measures reduce the energy use per unit of energy service. Examples would include measures with high energy savings, such as thermal insulation and envelopes of a building that reduce the energy use to maintain a comfortable temperature in homes, while other measures have a lower impact on energy savings, such as appliances that use less energy than other models to perform the same service. Both measures make an important contribution to limiting the increase in the Earth's global average surface temperature to $2^{\circ} \mathrm{C}$ above the preindustrial level. 
access to all the available information, essentially without cost, and that they use this information to maximise profits or minimise costs when making an investment decision.

5. While most renewable sources of energy are not yet competitive at current energy prices and costs without subsidies (Eurima, 2006), the drivers of and barriers to investment for energy efficiency and renewable energy technologies are often similar. The implications for renewable energy technologies of the different theories explaining underinvestment in energy efficiency are therefore discussed on the way, although the focus is on energy efficiency. Data from an OECD household survey regarding environmental behaviour is used to provide some evidence regarding drivers of investment in energy efficiency and renewable energy. Policies that would help overcome barriers to investment are also discussed.

6. This paper is organised as follows: section 1 discusses the literature that has identified underinvestment in energy efficiency, in the sense that investments that are found to be profitable are often not taken up. Section 2 discusses market failures that would explain an underinvestment in energy efficiency, including distortions in energy prices, principal-agent problems, credit constraints and imperfect availability or transmission of information. Closely related to this are theories discussed in section 3 , which explain underinvestment in energy efficiency with consumer choice behaviour that differs from the neoclassical paradigm of perfect rationality. Section 4 reviews theories that explain investment and energy conservation behaviour with attitudes, social norms and beliefs. The final section concludes and identifies areas where further research is needed.

\section{Apparent underinvestment in energy efficiency}

\section{Studies that identify underinvestment}

7. Several studies suggest that consumers often fail to adopt profitable energy efficiency investments. In other words, there is a difference between the optimal and the actual use of energy efficiency enhancing products. This phenomenon is known as the "energy-efficiency gap" or the energy efficiency paradox (Hausman, 1979, DeCanio, 1993, Howarth and Sanstad, 1995, Golove and Eto, 1996, Brown, 2001).

8. There are basically two ways to identify this type of underinvestment. One approach is to compute the net present value (NPV) of energy measures as the difference of forecasted energy savings, discounted with the market interest rate, and the upfront investment cost. If many projects with a positive NPV are not taken up, this would reflect underinvestment or, in other words, an implicit discount rate that is higher than the market rate. The second approach estimates consumers' valuation of initial investment costs on the one hand and of the present value of future energy savings on the other hand. If consumers attach a much larger weight to initial investment costs than to future energy savings, there will be underinvestment (Sanstad et al., 2006, Hausman, 1979).

9. The computation of the net present value of investments can be based on engineering estimates of savings or on estimates that come from actual energy use by households after they invested in energy efficiency. Studies that identified a significant energy efficiency gap based on engineering-economic analysis include National Academy of Sciences (1992), Rosenfeld et al. (1993), Brown et al. (1998) and (2001).

10. Many studies have provided evidence that consumers use high implicit discount rates when making efficiency-related decisions, in some cases, several times higher than the market rates on saving and borrowing (Train, 1985, Hassett et al., 1993, Sanstad et al., 2006). For instance, Hausman (1979) computed an average discount rate of about $25 \%$ for the purchase of air conditioners. 
11. Using the second methodology to identify an energy efficiency paradox, Allcott and Wozny, (2012) estimated the relationship between the expected price of gasoline and the purchase price for new vehicles. Their results suggest that consumers undervalue future gasoline costs relative to car purchase prices when they choose between automobiles with different energy efficiency. Consumers appeared to be indifferent between savings of one dollar of discounted future gasoline costs and of only 76 cents of the vehicle purchase price. The corresponding "implicit discount rate" for future gas costs that rationalizes market behaviour, was just under 15 per cent. Busse et al. (2012) found similar results, suggesting that consumers might "undervalue" future gasoline costs when purchasing cars. Their implicit discount rates ranged from negative values to $20 \%$ depending on different assumptions made, such as expected mileage of the vehicles, energy efficiency, and demand elasticity.

12. Other studies suggest that the energy efficiency gap may be severely overestimated and some question its existence. Critics pointed to a number of flaws in studies which found a large energy efficiency gap: the studies may have overstated potential energy savings, failed to fully take into account the costs of adopting new technologies, misrepresented the way consumers assess risk or ignored consumer heterogeneity (Allcott and Greenstone, 2012; Gillingham et al., 2013).

\section{Are energy savings overestimated?}

13. Evaluations of the energy efficiency gap often rely on ex ante engineering estimates of energy savings for certain technologies. If these estimates do not accurately reflect true energy savings, they may result in a biased estimate of the energy efficiency gap (Jacobsen and Kotchen, 2012). Metcalf and Hassett (1999) investigated attic insulation in the United States. They found that realised returns were smaller than suggested by engineering estimates, with $75 \%$ of their sample likely receiving less than a $13 \%$ annual return on their insulation investments. They concluded that there was no energy efficiency paradox, as median returns for investors - around $9.7 \%$ for attic insulation - did not significantly exceed those that one would expect from a capital asset pricing model (CAPM) ${ }^{3}$ analysis of the energy-conservation decision. However, it is important to note that the authors computed a mean return for attic insulation of about $11 \%$ and median returns of $9.7 \%$, while $25 \%$ of their sample had returns that were greater than $13.5 \%$. This evidence suggests that there is significant heterogeneity among consumers.

14. Actual energy savings have also been investigated in utility-sponsored programmes, with a wide range of results. A recent study by Auffhammer et al., (2008) tested whether utilities have been overstating electricity savings and underestimating costs associated with energy efficiency demand side management programmes. They found that the estimates of average savings and costs implied by their analyses were consistent with the average effects reported by the utilities over the same study period.

15. Overall these results suggest that engineering studies might overestimate future energy savings. The main explanations found by Nadel and Keating (1991) relate to erroneous assumptions in the engineering estimates, particularly over-estimating lighting system operating hours; ignoring complex interactions, such as rooms that are unheated or only partially heated; and quality control problems during measure installation, commissioning and maintenance. To the extent that engineering estimates overestimate energy savings, studies based on such estimates also overestimate the extent of underinvestment in energy efficiency. That said, not all studies that have identified large discount rates implicit in energy efficiency investment decisions are based on engineering estimates of energy use. In that sense, a bias in engineering estimates of energy savings cannot fully explain the so called energy efficiency gap.

3. It is an investment model that indicates will requires higher rates on returns on more risky investments. 


\section{Are costs underestimated?}

16. It is sometimes argued that some studies did not correctly assess the profitability of energy efficiency investments, as they failed to fully account for all adoption costs. This could include the time for acquiring information about the profitability of these investments or for installing the new equipment. It is particularly difficult to learn about the performance and costs of energy-efficient technologies and practices compared to more traditional equipment (Golove et al., 1996).

17. Even when information is potentially available, it is frequently costly to acquire, requiring time and money. This is part of the transaction costs faced by consumers that studies typically did not take fully into account (Howarth and Sanstad 1995, Brown 2001, Schleich and Gruber, 2008). A study by Hein and Blok (1994) found that transaction costs in large energy-intensive industrial firms ranged from 3 to $8 \%$ of total investment costs. Firms may also incur training expenses for operation and maintenance staff when they adopt new technologies. Anderson and Newell (2004) studied technology adoption decisions of manufacturing plants in response to government-sponsored energy audits. They found that approximately $35 \%$ of profitable investments suggested in energy audits were not implemented due to opportunity costs, e.g. the time that staff would have to spend analysing or implementing new production processes or maintaining new equipment and various project risks, including potential objections of personnel against new equipment or suspected maintenance problems. Typically those costs are not reflected in engineering cost estimates.

18. Koomey and Sanstad (1994) analysed different examples of product purchase decisions to test whether factors such as hidden costs or heterogeneity could inhibit the adoption of these efficient appliances or technologies. In the case of energy-efficient commercial lighting and consumer purchases of refrigerators, they found that hidden costs and heterogeneity did not seem to play any relevant role. Consumers appeared to use high implicit discount rates, even when hidden costs and heterogeneity were taken into account. The authors concluded that many profitable investments are not taken up for unknown reasons.

19. Another type of hidden costs is the possibility that qualitative attributes of more energy-efficient technologies are inferior to those of less efficient technologies. An example is the difference in colour and lightness between fluorescent and incandescent lighting (Jaffe et al., 2004). In the automotive sector, differences in fuel costs between cars are often related to differences in other attributes, such as size, weight and power (Berry et al., 1995, Busse et al., 2012). In some cases, more fuel efficient vehicles might have less desirable attributes, such as slow acceleration, less comfort and reduced maximum speed.

20. In conclusion, the ex-ante assessments of the profitability of energy investments may be overstated, as sometimes studies failed to fully account for all relevant costs. Yet, the evidence regarding this issue is mixed and it is not clear that hidden costs can fully explain apparent underinvestment in energy efficiency.

\section{Do risks related to energy efficiency investments explain slow adoption?}

21. The uncertainty surrounding energy savings, fluctuations in energy prices and the irreversibility of the investment imply that energy efficiency investments are particularly risky. As consumers tend to be risk-averse, such concerns have been found to be very important for decision-makers, strongly affecting consumer decisions (Hirst and Brown, 1990).

22. Jaffe et al. (2004) explored why the adoption of energy technologies is more sensitive to the initial cost of those measures than to the future energy savings associated with them. The authors hypothesized that the uncertainty about future energy prices is one possible explanation, as households 
may give a stronger weight to the certain initial investment costs than to uncertain future energy savings of equivalent value. They also conjectured that consumers might have reasonable expectations about future energy prices, and their decisions reflect those expectations. However, the proxies for these expectations used by researchers could be flawed. Researchers often use the current realised energy prices as a proxy for expected future energy prices. If this leads to an overestimation of the expected energy prices that consumers actually did use to make their decision, the weight given to the net present value of these savings will be underestimated.

23. Some authors argued that using a high discount rate for energy investment decisions can be rational. For example, it could reflect consumer risk-aversion given the uncertainty about future returns combined with the irreversibility of the investment in question (Sutherland, 1991 and 2003). According to Sutherland (1991) the capital asset pricing model (CAPM) implies that investors will require high returns on riskier investments in that case. Therefore, uncertainty concerning energy prices might explain the prevalence of high implicit discount rates.

24. In a model analysed by Hassett and Metcalf (1993), and Metcalf (1994), the concurrent presence of uncertainty regarding energy prices and of irreversibility of investments in conservation technologies result in a quantifiable benefit (the option value) of delaying a decision until some of the uncertainty is resolved. This implies that a rational consumer will apply a 'hurdle rate' to potential energy investments up to four times greater than the standard discount rate to make those investments attractive, slowing the diffusion of those technologies. The hurdle rate is the minimum acceptable rate of return on investment demanded by consumers. The authors explicitly modelled uncertainty and irreversibility and thus predicted investment rates in energy efficiency similar to the rates observed in the 1970s and 1980s in the United States. This analysis suggests that the slow diffusion of energy technologies might be the result of consumers' rational choice to minimise cost.

25. Conversely, Sanstad et al. (1995) argued that the Hassett and Metcalf model (1993) did not explain the high implicit discount rates that are sometimes observed in consumer decision-making. While Hassett and Metcalf demonstrated that the hurdle rate can be several time higher than the discount rate, Sanstad et al. (1995) showed that this relationship holds only for low discount rates (e.g. 5\%), while for higher discount rates, such as $30 \%$, the hurdle rates for irreversible investments under uncertainty are roughly similar to the consumer's discount rate as predicted by the conventional (neoclassic) model. The authors concluded that even when taking uncertainty and irreversibility into account, the Hassett and Metcalf model did not explain why consumers apply high implicit discount rates.

26. Baker (2012) pointed out that, while Hassett and Metcalf's conclusions make an intuitive case for yes/no decisions (such as whether to add insulation to a home), it is not clear that this analysis also applies to decisions regarding multiple technologies. The author investigated how uncertainty and irreversibility would impact a consumer's decision about when to buy which kind of a series of new products. She concluded that an option value decision model might not explain the energy efficiency gap for vehicles (such as buying a SUV instead of a compact car) or in other contexts with multiple choices.

27. Van Soest and Bulte (2001) considered the uncertainty of future technological progress and the irreversibility of investments from a firm's perspectives. They suggest that it may be rational not to adopt new technologies immediately that appear profitable, as a firm can benefit from waiting for the arrival of even better technologies. The relevance of risk related to technology adoption decisions of manufacturing plants was also demonstrated by Anderson and Newell (2004). They used data from the Industrial Assessment Centre's programme that offered free energy assessments to small and medium-sized manufacturers, suggesting that often companies did not adopt recommended projects due to risks associated with them. 
28. A number of studies suggest that uncertainty surrounding energy savings, fluctuations in energy prices and the irreversibility of the energy efficiency investment might partly explain their slow adoption. However, there are also studies that cast doubt on this hypothesis. Overall it remains unclear whether risk, uncertainty and irreversibility of some energy efficiency investments can explain the apparent underinvestment in energy-efficient technologies.

\section{The role of heterogeneity of consumers}

29. Although some technologies appear profitable on average, they might not be attractive for some part of the population (Jaffe et al., 2004). This can depend on characteristics, such as differences in preferences or in the expected use of the product. Depending on the size of the subset of the population for whom the investment is not attractive, this could be relevant as an explanation for slow adoption of energy efficiency investments (Gillingham and Palmer, 2013, Golove and Eto, 1996). For instance, Golove and Eto (1996) cited the example of consumers replacing an incandescent light bulb with a compact lamp. For consumers who use these bulbs relatively little, the profitability of this investment is reduced. Howart and Sanstand (1995) noted that individuals' specific habits and preferences play a role for whether or not energy conservation technologies are attractive for them. They cited the case of electric space heating that may be uneconomic for a typical home that is occupied throughout the entire year, but may constitute a low-cost energy alternative for a summer residence, where the upfront cost of more energy-efficient systems cannot be recovered because of low utilisation rates. Evidence on how differences in behaviour affect the profitability of energy retrofits is reported by Metcalf and Hassett (1999) regarding attic insulation. They computed a mean return for this investment of about $11 \%$, while in $25 \%$ of the cases the return was greater than $13.5 \%$. These differences in rates of return are largely dependent on the intensity of use. All these examples would imply that when there are differences in preferences or expected use, average returns could differ greatly from average returns for non-adopters or returns for the marginal adopters (Allcott and Greenstone, 2012).

30. More recently, Bento et al. (2012) pointed out that empirical analyses that ignore consumer heterogeneity in preferences may overestimate the undervaluation of future energy savings compared to purchase costs of cars. In their model consumers differed in their marginal willingness-to-pay (MWTP) for a future reduction in fuel costs. They showed that such unobserved consumer heterogeneity can bias the estimate of the MWTP for discounted future fuel costs downward. In other words, the extent to which consumers value a reduction in initial investment costs more than an increase in future fuel cost savings of equal size would be overestimated.

31. Overall, this review of the literature suggests that the extent to which there is underinvestment in energy efficiency might be exaggerated in a number of studies. Yet, results regarding those issues are often mixed and overall it does seem that many profitable investments are not taken up. There seem to be real barriers to investment in energy efficiency and this merits an in-depth review. In what follows, market failures that might help explain underinvestment in energy efficiency are discussed.

\section{Market failures that can explain an underinvestment in energy efficiency}

\section{Energy prices}

32. Environmental externalities represent a market failure as energy prices do not reflect the true marginal social cost of energy consumption (Gillingham et al., 2009). The environmental costs of energy use associated with burning fossil fuels, such as climate change due to greenhouse gas emissions are not included in what consumers pay for energy services (Golove and Eto, 1996, Jaffe and Stavins, 1994a). Therefore, the social consequences of under-investment in efficiency are proportional to the sum of individual instances of non-adoption (Sanstad et al., 2006). In the absence of appropriate environmental 
policy intervention, individuals do not have an economic incentive to minimise the external costs of pollution and greenhouse gas emissions. As a result, they over-consume energy and fail to adopt energysaving measures, resulting in an inefficient level of energy investment (Sutherland, 1991, Jaffe and Stavins, 1994a). While most of the energy gap literature focuses on underinvestment in energy efficiency from a private perspective at given market prices, externalities are another source of underinvestment from a social perspective.

33. A study reviewing energy efficiency policies (e.g. appliances standards, financial incentives, etc.) found that including environmental benefits, the related reduction in $\mathrm{CO}_{2}$ emissions and air pollutants may contribute an additional $10 \%$ to the value of energy savings from those programmes (Gillingham et al., 2006).

34. From a policy perspective, environmental externalities can be corrected through a Pigouvian tax that adds the equivalent of the external cost of emissions to the energy price. The resulting internalisation provides an incentive for customers to reduce their energy consumption and to adopt more energy saving measures.

\section{The role of capital constraints}

35. Financing constraints are thought to be one of the major barriers to investing in energy efficiency, especially for low-income households and cash-constrained industries (Hirst and Brown 1990, Golove and Eto, 1996, Schleich and Gruber, 2008). Clearly, the problem of lack of access to capital is relevant for any capital-intensive investment; it is not limited to energy-efficient or renewable energy technologies (Gillingham et al., 2009).

36. Energy-efficient equipment (e.g. lighting, HVAC, etc.) is generally more expensive than less energy-efficient alternatives, regardless of the market sector or building type. The cost to retrofit major building systems, upgrade a building's envelope, or install more efficient industrial machinery can represent a substantial upfront investment and may require debt financing. If the energy savings over the lifetime of the building or the machinery outweigh the initial investment cost, households and businesses would still be expected to invest. However, if their access to credit is limited, this might not be possible.

37. Weller (2007) provided evidence regarding credit constraints for low-income households, reporting loan denials in the US. His results are based on the Survey of Consumer Finances (SCF), which examined families' access to credit of any type. The report showed that the share of families with loan denials was $13 \%$ in 2004, with denial rates declining at higher income levels. Families with incomes in the top fifth of the income distribution, or those earning more than USD 88030 , had denial rates of $4.5 \%$ compared to $15.7 \%$ for families in the middle quintile, those earning between USD 34738 and USD 55 331. For lower-income families, the situation was even worse: families earning between USD 18500 and USD 34738 faced denial rates of $19.4 \%$. These results suggest that access to credit is particularly limited for low-income households, who are less likely to meet lenders' criteria for a specific loan.

38. A recent survey conducted in the United States reported that only a small fraction of households use home equity loans to finance energy retrofits. In particular, to finance energy investments only $6.5 \%$ of customers used a loan, an average of 58\% of customers used cash or checks and $14 \%$ used credit cards (Palmer et al. 2011). This reluctance to use loans may well be partly due to credit constraints. Berry (1984) discussed the Northeast Utilities survey suggesting that after the introduction of a specific loan for energy efficiency investments, the number of households making such investments increased by $7 \%$. This is further evidence suggesting that there are credit constraints for energy efficiency investments. 
39. Credit constraints for energy efficiency investments in the building sector may indeed be more severe than they are for other investments. Some studies noted that supply-side factors, such as perceived credit risk, high transaction costs, and asymmetric information may discourage lenders from offering loans for energy efficiency investments to individual households (Saheb et al., 2012, Palmer et al., 2012). The perceived credit risk is mainly due to the fact that financial institutions often lack the know-how to measure and verify energy savings. These depend on building types and construction periods, which differ a lot across the buildings sector and are difficult to assess for banks.

40. Providing lenders with support to judge the costs and profitability of energy efficiency investments for different buildings would facilitate their task to develop standardised loans for specific packages of measures (Saheb et al., 2012). An example for such an arrangement comes from Germany. The Kreditanstalt für Wiederaufbau (KfW), a government-owned development bank, bases its decision to provide a loan on an independent assessment by an expert. This programme has been very helpful to promote energy efficiency investments in the building sector.

41. Relatively small household investments in energy efficiency and renewable energy technologies can make loans uneconomic given fixed administrative costs. The typical loan size for an unsecured energy efficiency loan in the residential market is generally less than USD 10000 . Initial fees can be as high as USD 300-USD 400 (Palmer et al., 2012), indicating that the small volume of these type of loans can make them either very costly for customers or unprofitable for lenders.

42. Asymmetric information can also deter financial institutions from lending for energy efficiency or renewables investments. This can occur when lenders cannot distinguish ex ante between high-risk and low-risk borrowers. In that case, there could be adverse selection. If banks increase interest rates to protect themselves against losses from high-risk borrowers, some low-risk borrowers will withdraw from the market, although banks could lend to them at a profit if they had offered lower rates. There is a possibility that mainly low-risk borrowers would drop out reducing the average creditworthiness of the remaining borrowers as well as the lenders' profits (Palmer et al., 2012). Adverse selection can also occur if lenders are unable to assess the profitability of the investment (in terms of future savings) and thus the likelihood of repayment by borrowers (Golove and Eto, 1996). In that case, as well, it may be the investors with the most profitable investments who withdraw from the market first.

43. Customers could also turn to energy service providers, which are widespread in the public sector in the United States. Typically, energy service providers guarantee the equipment performance and the resulting energy savings for energy efficiency investments, sometimes providing financing themselves, sometimes sharing the resulting profits from energy savings with their customers. When consumers and energy providers establish guaranteed performance contracts, the energy provider has to guarantee the savings. If the future savings do not materialise, the provider pays for the difference (Zobler and Hatcher 2003). These mechanisms can improve access to financing for energy investments. However, energy service providers are often not interested in the residential sector for the same reasons that deter financial institutions from lending in this sector. In particular, energy saving possibilities for a single project are usually small compared to the transaction costs, especially in cases when the ownership of buildings is dispersed among many private owners (Grim 2005). Therefore, energy service providers typically limit their activity to public sector investments, where investment volumes tend to be larger. Satchwell et al. (2010) estimated that public and institutional markets, such as federal, state and local governments, schools, universities and colleges, accounted for about $84 \%$ of energy service company (ESCo) industry revenues in the United States.

44. These studies suggest that supply-side factors in the credit market may prevent lenders from offering adequate financial solutions for energy efficiency measures. To address the perceived credit risk, a better understanding of the risks associated with past lending programmes for energy efficiency 
investments could help to generate more lending for these activities. Evaluations of such programmes would help in this respect. Regarding the asymmetric information issue, the wide availability of credit scores, credit histories, bill repayments and other information can give lenders the ability to distinguish between different borrowers with different levels of risk (Vogel and Adams 1997).

45. Solutions that bundle energy-efficiency loans would help to overcome problems associated with small loans and lack of standardised loan products. To that end, collecting high volumes of loans would allow lenders to reap economies of scale regarding fixed costs and to standardise products (Palmer et al., 2012). The KfW programme in Germany provides a good example in this respect. The government negotiates conditions with KfW, such as the amount of loan funding available, the level of the subsidy to reduce interest rates on loans, but also the required energy performance of the buildings after the installation of energy upgrades. In addition, as $\mathrm{KfW}$ is a major financial institution active in German (Schröder et al., 2011), it can collect high volumes of loans reducing transaction costs. This scheme could be replicated in countries where similar financial institutions exist.

46. Although credit constraints are likely to be an important issue, empirical evidence regarding their importance for energy efficiency is scarce. One way to uncover credit constraints is to demonstrate that the likelihood for individuals to invest depends on income. If there was access to credit for all households, they would be expected to invest in any profitable technology, independently of their income. Hausman (1979) provided evidence for credit constraints based on this idea, observing that the implicit discount rate that consumers use to make decisions on the purchase of air conditioners decreases exponentially with income. For instance, the discount rate falls from 39\% for households with an income of under USD 10000 to $8.9 \%$ for households with an income between USD 25000 and USD 35000 . This is likely due to liquidity constraints, as middle and low-income households seem to take up only highly profitable investments.

47. Recent evidence comes from Ameli and Brandt (2014). The study, which is based on Household Environmental Behaviour and Attitudes, investigated which factors might drive household decisionmaking when it comes to the adoption of clean energy technologies. Households across eleven OECD countries were asked whether they installed different clean energy technologies between 2001 and 2011. The study found that in general investments depend positively on income, except for few technologies such as light bulbs, solar panels and heat pumps, and the marginal impact of higher income on the probability to invest decreases with income.

48. For instance, in the case of energy-efficient appliances Figure 1 shows how the predicted probability to invest evolves for an individual with only income changing. An increase in income leads to a big increase in the probability to invest for low-income levels, but this marginal impact decreases with income and finally levels off for high-income levels. These results provide clear evidence for financing constraints. Indeed, the initial upfront costs of energy measures seems to represent a large barrier to investment for low-income households, who may lack access to credit and may not have savings to cover the investment costs, but this barrier seems to be much less relevant for higher-income individuals. 
Figure 1.Changes in income and the predicted probability of investing in energy-efficient appliances

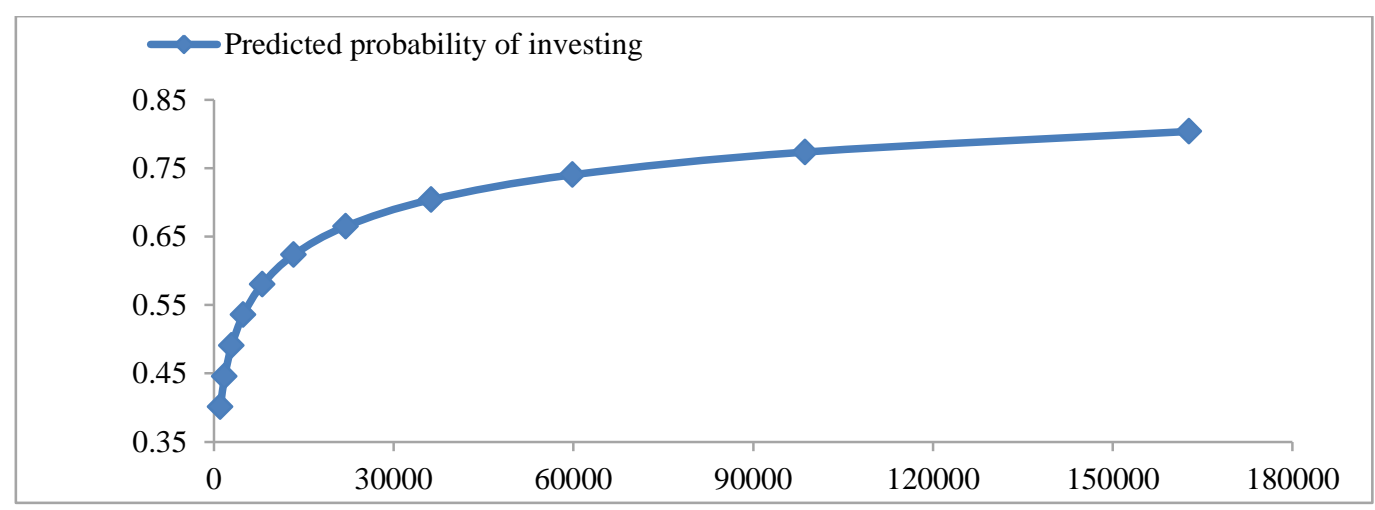

Source: Ameli and Brandt (2014)

49. From a policy perspective, lowering financing barriers could increase the affordability of energyefficient technologies, especially for consumers with limited credit access. In the United States, a programme called Property Assessed Clean Energy (PACE) offers financing solutions for investments in renewable energy and energy efficiency investments. Under PACE, local governments raise money through the issuance of bonds to then lend the money to customers who are willing to invest in renewable energy technologies or energy efficiency. Repayment over 20 years occurs via a special tax, which is collected as a line item on the property tax bill (Fuller et al., 2009, Ameli and Kammen 2012).

50. A more recent example in the United Kingdom is the government's Green Deal. Loans under the Green Deal, which are provided by accredited private organisations, are repaid via the energy bill. As only investments that are certified as profitable are allowed, energy bills should generally not increase as a result. Electricity suppliers will transfer customers' payments to the lender. Low-income households will have access to the Green Deal, as long as the investment that they are planning is approved as being profitable. However, the Green Deal, which is a relatively new programme introduced in 2013, has had difficulties picking up. In the first year only 1787 projects using Green Deal finance were implemented, a mere $1 \%$ of the projects which the government had aspired to install by then (DECC 2014).

51. Providing subsidised or guaranteed loans can also help low-income households to overcome financial constraints. Berry (1984) reviewed several utility programmes which encourage residential customers to invest in energy-efficient technologies by providing subsidised loans. In general, households were more likely to borrow when zero-interest loans were available compared to a situation when the interest rate was lower than the market rate, but still positive. In addition, households who took out loans made larger investments in retrofits, although causality is unclear, as households who made larger investments might be also those who were more likely to require a loan.

52. Other incentive schemes, such as direct subsidies, tax credits or rebates can also be relevant policy instruments to lower the upfront cost of energy investments, thus alleviating credit constraints. While internalising external costs of emissions by increasing energy prices is thought to be a more efficient instrument in the absence of credit constraints, subsidies to adopt low-emission technologies may be a more effective and less costly policy instrument than higher energy taxes, when credit constraints are present, as many households may simply not have the means to react to the price signal. 
ECO/WKP(2015)40

\section{Principal-agent or split incentive problem}

53. Principal-agent problems can arise when intermediaries are involved in decisions to purchase energy-saving technologies, or persons responsible for investment decisions are different from those benefiting from the energy savings. One frequently cited example is the landlord-tenant relationship. Since the tenant would typically benefit from the savings on the energy bill, there are hardly any incentives for the owner to invest. At the same time, incentives for tenants to invest are weakened, because they are more likely than owners to move before they reap the full benefits of their investment (Jaffe \& Stavins 1994a, Schleich and Gruber, 2008).

54. Murtishaw and Sathaye (2006) attempted to quantify the magnitude of the principal-agent problem in several areas of residential energy use in the US. They determined the cases involving a principal-agent problem according to the user's ability to choose the home appliances (such as refrigerators) and the user's responsibility for paying the associated energy costs. For instance, if the person paying the utility bill is not the person using the appliance, the user may consume more energy services than she would if she had to pay the bill herself. Similarly, if the person paying for energy is not the person choosing the appliance, the buyer of the appliance will generally choose among the cheapest, and often least efficient options. The authors found that $35 \%$ of residential energy use might be affected by at least one split incentive problem.

55. Davis (2010) compared the market penetration of efficient appliances (such as refrigerators, dishwashers, light bulbs, room air conditioners, and clothes washers) between homeowners and renters using household data from the National Survey in the United States. Typically, these devices are bought by the landlord, while the tenant pays for the utility bills. The results showed that, controlling for household income and other household characteristics, renters were significantly less likely to have energy-efficient refrigerators, clothes washers and dishwashers. The difference between the shares of owners and renters owning energy-efficient devices ranged between 1 and 10 percentage points. These results are consistent with the split incentive problem. An alternative explanation could be that landlords might prefer to buy cheap inefficient devices because appliances might have a shorter lifespan in renter occupied units. As tenants do not own the appliances, they might not treat them properly, increasing maintenance costs.

56. Ameli and Brandt (2014) found that owners are more likely to invest than renters for the majority of the energy technologies analysed in their paper, with a substantially larger magnitude of the effect for relatively immobile investments (such as windows and thermal insulation).

57. On the other hand, there may be moral hazard from the tenant's side when water and energy costs are included in the rent as a lump sum. In such cases tenants have low incentives to save energy. Gillingham et al. (2012) quantified the magnitude of split incentive and moral hazard issues in Californian dwellings. They found that it is important who pays for heating and cooling. Households paying for heating were $16 \%$ more likely to change the heating setting at night. Moreover, they analysed insulation split incentive issues between the owner and occupant. The owner-occupied dwellings were $20 \%$ more likely to be insulated in the attic or ceiling and $13 \%$ more likely to be insulated in the exterior walls than renter-occupied dwellings. Also Levinson and Niemann (2004) provided empirical evidence for a principal-agent problem when landlords pay for heat. They used the U.S. Department of Energy's Residential Energy Consumption Survey (RECS) to show that on average, apartments for which heat is included in the rent are kept warmer than those where tenants pay for heat.

58. The split incentive problem that arises in the rental housing market may also be interpreted as an information problem. If investments in energy-efficient measures were capitalised in the purchase and rental prices of the corresponding property, the owner could recover the investment cost. In principle, in a well-functioning market, the rent of a more energy-efficient home should always be higher than the rent of 
a less energy-efficient dwelling, with the difference reflecting the value of discounted energy savings. Yet, it may be difficult for landlords to effectively convey information about the energy efficiency characteristics of the home they offer, as this is difficult to observe. In that case, the landlord might not be able to recover the cost of energy efficiency measures through higher rents, which can lead to underinvestment (Jaffe et al., 2004). In addition, in many countries owners are not allowed to raise the rent as they wish, unless the tenant changes. A law allowing owners to increase the rent after implementing energy efficiency measures could solve this issue. In Germany, this seems to have helped to diffuse energy efficiency measures in a market with a high share of rental housing.

59. Other solutions include programmes aimed at improving information, such as labels indicating the energy performance of appliances and buildings. Appliance standards and building codes can also help to convince potential buyers or renters of a minimum energy efficiency performance of the products on offer. Information programmes may then be used to induce savings beyond minimum standards (Gillingham et al., 2012).

\section{Informational problems}

60. Informational problems are often given as reasons why consumers systematically underinvest in energy efficiency (Sanstad et al., 2006). This can include lack of access to information, lack of incentives to gather information owing to the costs associated with it, the accuracy of available information, and the ability to use or act upon information (Golove and Eto 1996). Lack of information can concern different aspects of energy products, such as uncertainties associated with energy price fluctuations, future operating costs or energy performance. For instance, very few consumers actually know the costs and benefits of different energy solutions (e.g. photovoltaics), how much energy they use in their homes or what rates of return to expect from energy efficiency measures (Hawken et al., 1999).

61. Evidence on households' knowledge about energy bills is provided by Ameli and Brandt (2014). Respondents were asked to get hold of their energy bills before answering the OECD Survey on Environmental Behaviour and Attitudes, but only about 55\% were able to provide information about their energy spending on average across countries. Even fewer households were able to provide information about their energy use in volumes, less than $19 \%$ on average across countries. At the same time, households who were metered were more likely to invest in more energy-efficient appliances than those who were not. Households who were able to provide information about their energy bill were more likely to invest in light bulbs. Those who were able to provide information about the number of kilowatt hours consumed, were more likely to invest in energy-efficient appliances.

62. Attari et al. (2010) provided evidence on households' misperceptions about energy use or savings. They reported results from a national US survey. When asked for the most effective strategy that households could implement to conserve energy, most participants mentioned curtailment (e.g., turning off lights, driving less) rather than efficiency improvements (e.g., installing more efficient light bulbs and appliances), which are much more effective. This study suggests that there was relatively little knowledge regarding the effectiveness of different energy saving measures. Such limited knowledge is likely to lead to underinvestment in energy efficiency.

63. Information problems are also relevant in the automotive sector, where consumers do not correctly assess the fuel economy of cars. Larrick and Soll (2008) used different experiments to show that there is a systematic misperception of gas savings when fuel efficiency is expressed as miles per gallon (MPG). They demonstrated that consumers tend to believe that the amount of gas consumed by an automobile decreases as a linear function of a car's MPG, while it follows a curvilinear - similar to hyperbolic - function. In other words, most people consider a 1 MPG increase in fuel efficiency to have the same impact in terms of gasoline saved on a given distance regardless of the starting point, while it actually results in larger gas savings for more inefficient cars. In Larrick and Soll's experiments, people 
were asked to decide which option would allow consumers to reduce their gasoline consumption per 10000 miles more: replacing a car that reaches 34 MPG with another vehicle which reaches 50 MPG or a car which reaches 16 MPG with another vehicle that reaches 20 MPG. The majority of respondents (64\%) chose the first option, which is wrong. This experiment demonstrated that people underestimated the value of removing the most fuel inefficient vehicles.

64. Similar evidence is provided by Allcott (2013), who used data from the Vehicle Ownership Alternatives Survey to show that consumers misperceive the fuel economy of cars, either by underestimating the financial savings or by being subject to the MPG illusion. His results suggest that half of the respondents were imperfectly informed about the difference between the gasoline costs of their current and second choice vehicles. This misunderstanding resulted from two factors: some consumers incorrectly categorised similar vehicles as having exactly the same MPG. Others, who correctly assessed the MPG difference, overstated the importance of the difference.

65. Further evidence is provided by Turrentine and Kurani (2007), who asked 57 households to assess the role of fuel economy in vehicle purchases. They found that few households understood the financial calculations behind payback of investments and that even those who did, did not apply such knowledge to their vehicle purchase and use. This lack of knowledge and information leads consumers to underestimate gasoline costs and savings over time.

66. Information problems can also occur when the information between two parties engaged in the transaction is asymmetric, potentially leading to adverse selection. Producers or sellers of energy-efficient equipment are, in general, more informed about the characteristics and performance of equipment than prospective buyers. In some cases, sellers cannot convince buyers of the actual benefits of energy efficiency investments. Howart and Sanstad (1995) results suggest that sellers of energy-efficient technologies are unable to transfer this information to customers, as some product characteristics related to energy efficiency cannot be observed ex ante. Therefore, customers might not fully take energy efficiency characteristics into consideration in their purchase decisions.

67. Studies suggest that providing independent information can help sellers to overcome information problems to some extent. Stern and Aronson (1984) tested the effect of bringing in an independent information provider. Thousand households in New York received information about energy savings from air conditioning systems. Fifty per cent of the households received the information from the local electricity utility, while the other half received information from the state regulatory agency for utilities. The authors observed different energy saving behaviour between the two groups: households reached by the state agency saved about eight per cent more electricity than the households contacted by the local electricity utility. This experiment underlined the need for independent sources of information that customers perceive as trustworthy in order to change behaviour.

68. More generally, policies which aim at improving customers' information about lifetime energy costs and energy savings of goods can be an effective strategy to promote the take-up of energy-efficient technologies (Costa et al., 2013, Kallbekken et al., 2012, Ayers et al., 2009). Kallbekken and his coauthors conducted a natural field experiment to test the impact of information on lifetime energy cost of appliances through a label and training of sales staff on purchase decisions. The authors found no significant effects for fridge freezers, while for tumble driers the treatment effects of labels and training reduced average energy use by $4.9 \%$ and $3.4 \%$, respectively.

69. Labels can help consumers learn about the energy performance of products and make comparison between different models. Typical examples are energy labels for new appliances and fuel economy labels for new cars (Gillingham et al., 2013). Newell and Siikamäki (2013) investigated the impact of energy efficiency labelling on consumer choices. Their analysis suggests that information on the economic value 
of saving energy, energy use and also labels endorsing a model (Energy Star) or giving a grade have a substantial impact in terms of encouraging the choice of energy-efficient appliances. Newell et al. (1999) investigated whether government regulations, such as the introduction of energy labels, had affected energy-efficiency innovation. They found that the responsiveness of energy-efficient product innovation for air conditioners and water heaters to energy prices increased after 1981 and 1977, which were the years when energy efficiency labelling was introduced for both products.

70. Some information programmes which provide feedback to customers on energy use can also help to decrease energy consumption (Ayers et al., 2009). Recent work by a company called OPOWER showed that this effect can be realised at large scale. OPOWER partnered with utilities across the United States to send energy use reports to residential electricity and natural gas consumers. Those reports displayed each household's energy consumption, compared it with that of similar households, and provided energy conservation tips. The data showed that the average programme reduced energy consumption by 2 $\%$ (Allcott 2011).

71. Novel approaches, such as nudging consumers could be another policy option to promote energy conservation. A recent example comes from the UK government. Families are being offered an atticclearing service as an incentive to insulate their lofts at the same time under a government-backed scheme to conserve energy. Workers clear lofts while installing insulation and take away any unwanted items to charity shops. Early results show that the system significantly increased the number of households insulating their roofs (The Guardian 2013). This case study suggests that the idea of "nudging" consumers can help them to make better choices.

72. Moreover, important externalities can be generated when schemes and programmes, such as utility conservation programmes increase the availability of information and consumers' interest in energyefficient goods and services (Blumstein and Harris 1993). In that case, even consumers who do not participate in utility programmes are more likely to adopt energy-efficient technologies and practices than they would be in the absence of such programmes. Eto et al. (1996) dubbed this process as programme spillovers, where the new user of energy technologies diffuses information about the product's usage, characteristics and performance and others decide to take up energy measures thanks to the additional knowledge acquired.

\section{Behavioural issues}

73. One explanation for underinvestment in energy saving technology is that customers fail to behave as predicted by rational choice theory (Kahneman and Tversky 1979, Shogren and Taylor 2008, Tietenberg 2009). Tversky and Kahneman were the first to describe that under uncertainty consumers systematically violate the axiom of rationale choice. Often choice behaviour is mainly led by perceptions and beliefs based on available information and influenced by attitudes and preferences rather following the basic principles of neoclassical decision theory (McFadden 1999). If customers apply simplified decisionmaking processes, by using only a subset of the available information for complex decisions or applying simple decision rules, also called heuristics (Wilson and Dowlatabadi 2007, Della Vigna 2009), this is referred to as bounded rationality. Psychologists (Simon, 1959; Tversky and Kahneman, 1981) have often demonstrated that individuals' ability to acquire and absorb disparate pieces of information is limited.

74. The crucial question is whether bounded rationality can lead to a systematic underinvestment in energy-efficient technologies (Gillingham et al., 2009, Della Vigna 2009). This could happen if simplified or biased decision making led individuals to give a significantly higher rating to initial investment costs than to future energy savings. The data used in Ameli and Brandt (2014) suggest that this is indeed the case for a considerable fraction of households, who are less likely to invest in heat thermostats and solar panels at the same time. Similarly, Anderson and Newell (2004) found that firms are about $40 \%$ more responsive 
to investment costs than to energy savings, while Jaffe and Stavins (1995) found that the technology cost effect on investment decisions is nearly three times larger than the energy price effect. Hassett and Metcalf (1995) found an even larger difference, which was eightfold. One explanation would be that there are financial constraints so that some consumers have no choice but to give a high weight to initial investments costs in their decision making. Yet, there are other explanations related to bounded rationality.

75. A bias towards initial investment costs could be due to the salience effect. This occurs when people tend to weigh information in proportion to its vividness and give more importance to easily observable factors (Yates and Aronson 1993). Regarding energy efficiency investments, consumers may tend to perceive the upfront cost easily, because it is relatively large and directly observable, while assessing the total value of energy savings over the life of an investment is more difficult given the uncertainty surrounding energy savings and fluctuations in energy prices.

76. The status quo bias is another phenomenon that might explain consumers' stronger emphasis on initial costs than on future energy savings. Kahneman and Tversky (1979) suggest that people normally perceive outcomes as losses and gains relative to a reference point, usually the status quo. The authors' empirical results suggest that people exhibit loss aversion in decision-making under uncertainty, giving much more weight to a loss than to an equivalent uncertain gain. In the energy efficiency context, loss aversion can partly explain why consumers do not take up profitable investments, as they weight the certain initial costs (the loss) much more strongly than future uncertain benefits, even if these are in principle of an equivalent value. Some authors suggest that in the automotive sector, loss aversion can explain the failure to adopt energy-efficient vehicles (Greene et al., 2009). When customers have to decide whether to purchase a more efficient vehicle, they have to take into account the uncertainty surrounding the future fuel prices, the performance of the vehicles and the kilometres driven. If consumers are loss-averse, they will give a higher weight to the higher investment cost of efficient vehicles than to future energy savings of equivalent value.

77. Furthermore, Loewenstein and Prelec (1992) hypothesized that people weight events according to the magnitude of the outcome, so high discount rates apply to small outcomes and lower discount rates apply to large outcomes. This behavioural bias can explain the high implicit discount rates observed for energy efficiency investments as energy savings per period are small, while initial costs are large.

78. Another explanation would be the existence of hyperbolic discounting, which is timeinconsistent. Preferences are time-consistent when decisions are independent of when they are taken (Wilson and Dowlatabadi 2007, O'Donoghue and Rabin 1999). This requires that the future will be discounted at a fixed rate, independently of when costs and benefits actually occur (Gintis 2000), and the relative valuation of two events does not change. However, several studies found that individuals do not make decisions in a time-consistent way and their discount rate for the same event changes over time, namely it increases as the event approaches (Harris and Laibson 2001, Frederick et al., 2002, Della Vigna 2009). For instance, consumers may prefer USD 100 in 31 days over USD 99 in 30 days, but also prefer USD 99 today over USD 100 tomorrow. This happens because with an intertemporal choice under hyperbolic discounting the later event is discounted more with respect to the earlier event, as the two events approach, even if the distance between them remains the same. This means that individuals may appear to be willing to adopt energy-efficient investments in the future, but as the event approaches their inclination to do so vanishes, as they discount future benefits more strongly with respect to the cost incurred before. Tsvetanov and Segerson (2013) show empirically that households' refrigerator choices seem consistent with this framework, demonstrating that hyperbolic discounting could be an explanation for underinvestment in energy efficiency.

79. Recently, Attari et al. (2010) provided evidence on household perceptions of energy use or savings. They reported results from a national US survey. Participants were asked to estimate the number 
of energy units typically used in one hour by different appliances and devices (e.g. stereo, dishwasher). They were also asked to estimate the number of energy units that would be saved by different activities (e.g. changing washer temperature). To help participants make those comparisons, both questions provided a reference point indicating that a 100-Watt incandescent bulb uses 100 units of energy in one hour. Participants underestimated energy use and savings by a factor of 2.8 on average, with a tendency to overestimate energy savings related to low-energy activities slightly, while underestimating energy savings related to high-energy activities significantly. The authors suggest that respondents' difficulty in judging energy use and savings might partly result from an anchoring bias. The reference point provided in the task might have served as an anchor for participants' estimates, causing them to be too close to the reference point. If an anchoring bias led people to underestimate energy savings of an energy efficiency investment, this could lead to underinvestment.

80. Wilson and Dowlatabadi (2007) cited other types of biases and heuristics, such as the "recognition heuristic" that occurs when people favour familiar choices (e.g. select the option that was chosen last time) or the "elimination heuristic" that arises when decision makers immediately reject alternatives with a particular attribute (e.g. the most expensive option).

81. Testing bounded rationality and biases in decision-making empirically is quite a difficult task. Friedman and Hausker (1988) attempted to develop a predictive behavioural model based on these issues. The model analysed households' energy consumption in response to a tiered-rate structure of electricity prices. It turned out that households responded to the total monthly bill independently of the tiered rate that had determined it, apparently using average energy prices for their calculation of estimated energy bills instead of marginal energy prices. The authors' model suggests that consumers will over-consume energy with increasing block rates, because they underestimate energy savings when total volumes consumed are high, while they under-consume energy with declining block rates. Friedman (2002) tested this model by using monthly consumption and billing data from about 7000 households in California. Results suggest that household behaviour is better explained by a model based on bounded rationality rather than one based on utility maximization. Further evidence was provided by Kempton and Montgomery (1982) who conducted a survey analysing how consumers perceive and measure residential energy use. They found that consumers based their decisions on current rather than expected future energy prices when they evaluate energy efficiency investments. This will lead to an undervaluation of future energy savings with increasing prices and an overestimation of energy savings with declining prices.

82. From a policy perspective, information programmes can be useful to address behavioural failures. Providing more reliable information can reduce uncertainty in the decision-making process leading consumers to make better decisions. The introduction of product standards or energy labels can also alleviate problems with information processing, such as computing energy savings or assessing the profitability of energy investments. Product standards set a minimum level of energy performance or energy standards that the product must meet thus helping consumers to learn about energy use.

83. Market failures as well as behavourial issues that impede investment in energy efficiency or renewable energy can be addressed with a number of policy instruments that have been discussed in the text. Table 1 provides an overview. 
ECO/WKP(2015)40

Table 1. Main barriers to energy investment and policy solutions

\begin{tabular}{|c|c|}
\hline Barriers to energy investment & Policy responses \\
\hline $\begin{array}{ll}\text { Market Failures } \\
\text { - } & \text { Energy prices } \\
\text { - } & \text { Capital constraints } \\
\text { - } & \text { Split incentive problem } \\
& \\
\text { - } & \text { Information problems }\end{array}$ & $\begin{array}{l}\text { - Pigouvian tax } \\
\text { - Financing loan, direct subsidies, tax } \\
\text { credits } \\
\text { - Law allowing owners to increase the rent } \\
\text { after implementing EE, information } \\
\text { programmes } \\
\text { - Information programmes (peer- } \\
\text { comparison feedback, nudge), energy } \\
\text { standards/labels }\end{array}$ \\
\hline $\begin{array}{l}\text { Behavioural issues } \\
\text { - } \quad \text { Bounded rationality } \\
\text { - Heuristic decision-making }\end{array}$ & $\begin{array}{l}\text { - Information programmes } \\
\text { comparison feedback, nudge), energy } \\
\text { standards/labels }\end{array}$ \\
\hline
\end{tabular}

\section{Attitudes, socioeconomic characteristics and beliefs}

84. Social psychologists have attempted to analyse how socioeconomic attributes and psychological factors correlate with residential energy use and more broadly a relationship is often observed between individuals' characteristics and environmental behaviour.

85. Environmentally responsible behaviour, that attempts to limit negative environmental impacts, such as energy-saving actions, has been shown to correlate with socioeconomic attributes, psychological factors and social context (Olli et al., 2001, Kollmus et al., 2002). Olli et al. (2001) correlated environmental and ecological attitudes with socio-demographics (e.g. gender, age, education, income), political attitudes (e.g. conservatism, radicalism), environmental knowledge, and social context (e.g. social networks within environmental organizations). They found that people, who showed social participation, e.g. as a member of a non-governmental organisation (NGO), were more likely to be engaged in responsible environmental behaviour. Likewise Ameli and Brandt (2014) results suggest that membership in a NGO correlates positively with households' technology adoption for energy-efficient appliances, light bulbs, heat thermostats, thermal insulation and energy-efficient windows. For solar panels and heat pumps households engaged in an environmental NGO are more likely to invest than others. Social participation is not only a significant variable for all technologies, but the corresponding marginal effects are also quite high. For instance, households involved in NGOs are about 8 percentage points more likely to invest in energy-efficient appliances than households who are not in a NGO.

86. Olli et al. (2001) suggest that women and older people exhibit more environmental friendly behaviour than men and younger people. While Ameli and Brandt (2014) did not find any correlation between gender and the propensity to invest, they did find that some investments, such as energy-efficient windows, heat thermostats, thermal insulation and light bulbs, depended positively on age, while the probability to choose heat pumps decreased with age. This might imply that older respondents preferred well-known energy efficiency measures, while younger respondents were more open towards newer and more complex technology. 
87. Olli et al. (2001) also found that environmental knowledge had a positive effect on responsible behaviour, as persons more familiar with environmental problems and their causes were more likely to take energy conservation actions. Quite surprisingly, Ameli and Brandt (2014) found that understanding the causes of climate change did not raise the probability to invest, nor did the willingness to make compromises to solve environmental problems. In most cases these variables were insignificant.

88. Guerin et al., (2000) reviewed US studies on residential energy use from 1975 to 1998 , to identify predictors of energy consumption. They suggest that households' attitudes (e.g. comfort, health concerns, environmental knowledge) correlated with the propensity to change behaviour, while households' characteristics (e.g. age, income, household size, physical size of house) better predicted the actual energy-consumption.

89. Kempton et al., (1992) studied room air-conditioner usage to understand how energy consumption is determined by user needs and their behaviour. Surprisingly, they found many noneconomic factors limiting air-conditioner use. Motivations included very different reasons, such as health (e.g. arthritis), safety (e.g. never left the air-conditioner on when out of the room), comfort and differences in physiological characteristics (e.g. body's heat tolerance). Their data suggest that consumers mainly used air-conditioners according to their beliefs and preferences rather than a payback calculation.

90. The literature on environmental behaviour suggests that household energy use appears to be related to socio-demographic variables and households' attitudes, which influence behaviour. Specific household characteristics or lack of environmental knowledge might partially explain the non-adoption of energy conservation technology.

\section{Conclusion}

91. This paper discusses different hypotheses explaining underinvestment in energy efficiency that have been put forward in the literature. Over the last 30 years, the debate has continued over why consumers sometimes fail to adopt seemingly profitable energy-efficient products and practices.

92. The size and even the existence of this underinvestment are still questioned. The extent of this phenomenon is likely to be less important than the most optimistic studies suggest. In fact some studies that have shown a wide range of unexploited possibilities to save energy while lowering costs, might have overstated potential energy savings, failed to fully take into account the costs of adopting new technologies, ignored consumer heterogeneity or misrepresented the way consumers assess risk.

93. Yet, while unexploited potential for energy savings at negative costs is likely lower than the most optimistic studies suggest, there seem to be many barriers to investment in energy efficiency. Such barriers include energy prices that do not reflect the marginal social cost of energy consumption, credit constraints, principal-agent or split incentive problems, and consumers' lack of information about the availability of energy-efficient technologies or savings associated with them and bounded rationality. What barriers are most relevant and how they compare to each other might be empirically investigated in future research.

94. Targeted policies are required to address specific barriers for different groups of consumers. For instance, credit constraints are more relevant for low-income households and lifting these constraints would likely promote investment for this group. Direct subsidies, tax credits or rebates can also be relevant policy instruments to lower the upfront cost of energy investments. While internalising external costs of emissions by increasing energy prices is thought to be a more efficient instrument in the absence of credit constraints and bounded rationality, subsidies to adopt low-emission technologies may be a more effective and less costly policy instrument than higher energy taxation, when credit constraints are present or when bounded rationality leads consumers to overvalue initial costs relative to future energy savings. 
95. Providing more reliable information can reduce uncertainty and asymmetric information addressing associated market failures and leading consumers to improve their decisions. This can include product standards or energy labels. Those instruments set a minimum level of energy performance or energy standards that the product must meet, helping consumers to better evaluate the products' energy efficiency characteristics. Innovative approaches, such as "nudging" might complement these information policies, by encouraging consumers to take up clean energy investments. 


\section{BIBLIOGRAPHY}

Allcott H., and S. Mullainathan (2010), "Behavior and energy policy", Science, 327, pp. 1204-1205.

Allcott H. (2011), "Social norms and energy conservation”, Journal of Public Economics 95, pp. 10821095.

Allcott H. (2013), "The Welfare Effects of Misperceived Product Costs: Data and Calibrations from the Automobile Market”, American Economic Journal: Economic Policy 2013, 5(3): pp. 30-66.

Allcott H., and N. Wonzy (2012), "Gasoline prices, fuel economy, and the energy paradox", NBER working paper series, Working Paper 18583.

Ameli N., and N. Brandt (2014), "Determinants of households' investment in energy efficiency and renewables - evidence from the OECD survey on household environmental behaviour and attitudes." OECD Economics Department Working paper series 1165.

Ameli N., and D.M. Kammen (2012), "Clean energy deployment: addressing financing cost", Environment Research Letters 7 (2012):034008.

Anderson, Soren T. and R. G. Newell (2004), "Information Programs for Technology Adoption: The Case of Energy-Efficiency Audits", Resource and Energy Economics 26(1): 27-50.

Arimura T., S. Li, R. Newell and K. Palmer (2011), "Cost-Effectiveness of Electricity Energy Efficiency Programs”, Resources for the Future Discussion Paper 17556.

Ayers I., S. Raseman and A. Shih (2009), "Evidence from Two Large Field Experiments that Peer Comparison Feedback Can Reduce Residential Energy Usage”, NBER Working Paper 15386.

Attari S., M. DeKay, C. Davidson and W. de Bruin (2010), Public perceptions of energy consumption and savings", PNAS Early Edition, vol. 107, n. 37 16054-16059.

Baker E., (2012), "Option Value and the Diffusion of Energy Efficient Products". Energy Journal 33 (4):49-59.

Barr S., Gilg A. and N. Ford (2005), "The household energy gap: examining the divide between habitualand purchase-related conservation behaviours", Energy Policy 33 1425-1444.

Bento A., S. Li and K. Roth (2012), "Is there an Energy Paradox in Fuel Economy? A note on the role of Consumer Heterogeneity and Sorting Bias", Economics Letters 115 (1):44-48 .

Berry L. (1984), "The Role of Financial Incentives in Utility-Sponsored Residential Conservation Programs: A Review of Customer Surveys". Evaluation and Program Planning 7: 131-41.

Berry S., J. Levinsohn and A. Pakes (1995), “Automobile Prices in Market Equilibrium”. Econometrica 63 (4): 841-90.

Blumstein C., and J. Harris (1993), “The Cost of Energy Efficiency”, Science 261: 970. 
Brown M. A., M. D. Levine, J. P. Romm, A. H. Rosenfeld, and J. G. Koomey (1998), "EngineeringEconomic Studies of Energy Technologies to Reduce Greenhouse Gas Emissions: Opportunities and Challenges", Annual Review of Energy and the Environment 23, 287-385.

Brown M.A. (2001), "Market failures and barriers as a basis for clean energy policies", Energy Policy 29 pp. 1197-1207.

Chandler S., and M. Brown (2009), "Meta-Review of Efficiency Potential Studies and Their Implications for the South", Georgia Tech Ivan College of Public Policy Working Paper 51.

Costan D. L., and M. E. Kahn (2013), "Energy conservation "nudges" and environmentalist ideology: evidence from a randomized residential electricity field experiment", Journal of the European Economic Association 11(3):680-702.

Davis, L. W. (2010), "Evaluating the Slow Adoption of Energy Efficient Investments: Are Renters Less Likely to Have Energy Efficient Appliances?", National Bureau of Economic Research, Working Paper 16114.

DeCanio, S. J. (1993), "Barriers within firms to energy-efficient investments", Energy Policy 21 (9) 906914.

Della Vigna S. (2009), "Psychology and Economics: Evidence from the Field". Journal of Economic Literature 47 (2): 315-372.

Eto, J., S. Kito, L. Shown and R. Sonnenblick (1995), "Where Did the Money Go? The Cost and Performance of the Largest Commercial Sector DSM Programs". Lawrence Berkeley National Laboratory Working Paper No. LBL-38201.

Eurima (2006), "Cost-Benefit Analysis of the existing building stock”. Eurima, Brussels.

Friedman L. and Hausker K. (1988), "Residential Energy Consumption: Models of Consumer Behavior and Their Implications for Rate Design", Journal of Consumer Policy 11: 287-313.

Friedman L. (2002), "Bounded Rationality versus Standard Utility-Maximization: A Test of Energy Price Responsiveness", In Judgments, Decisions, and Public Policy, ed. R Gowda, J Fox, pp. 138-73. New York: Cambridge University Press.

Frederick S., G. Loewenstein and T. O’Donoghue (2002), "Time Discounting and Time Preference: A Critical Review", Journal of Economic Literature, vol XL 351-401.

Friedrich K., M. Eldridge, D. York, P. Witte and M. Kushler (2009), "Saving Energy Cost Effectively: A National Review of the Cost of Energy Saved through Utility-Sector Energy Efficiency Programs",. ACEEE Report No. U092.

Fuller M, Portis S and D. M. Kammen (2009), "Towards a low-carbon economy: municipal financing for energy efficiency and solar power", Environment 51(1):22-32.

Gillingham K, Newell R and K. Palmer (2006), "Energy Efficiency Policies: A Retrospective Examination", Annual Review of Environment and Resources 31: 161-92.

Gillingham K., R. G. Newell and K. Palmer (2009), "Energy Efficiency Economics and Policy”, Resources for the future, discussion paper RFF DF 09-13. 
Gillingham K., M. Harding and D. Rapson (2012), "Split Incentives and Household Energy Consumption", Energy Journal 33 (2):37-62.

Gillingham K., and K. Palmer (2013), "Brinding the Energy Efficiency Gap: Insights for Policy from Economic Theory and Empirical Analysis", Resources for the future, discussion paper RFF DF 1302.

Gintis H. (2000), "Beyond homo economicus: evidence from experimental economics", Ecological Economics 35 311-322.

Golove W. H., and J. H. Eto (1996), "Market barriers to energy efficiency: a critical reappraisal of the rationale for public policies to promote energy efficiency", Lawrence Berkeley National Laboratory Report (available at http://eetd.lbl.gov/EA/EMP/reports/38059.pdf).

Greene D., J. German and M. Delucchi (2009), "Fuel Economy: The Case for Market Failure", In Reducing Climate Impacts in the Transportation Sector, edited by D. Sperling and J. Cannon: Springer Science.

Greene D. (2011), “Uncertainty, loss aversion, and markets for energy efficiency”, Energy Economics 33 (2011) 608-616.

Grim M. (2005), "Energy Performance Contracting: an opportunity for the private service building sector or a tool for public buildings only?", In: Proceedings of the ECEEE Summer Study 2005.

Guerin G.A., Yust B.L. and J.G. Coopet (2000), "Occupant predictors of household energy behaviour and consumption change as found in energy studies since 1975", Family and Consumer Sciences Research Journal 29:48-80.

Haas R., and P. Biermayr (2000). "The Rebound Effect for Space Heating - Empirical Evidence from Austria". Energy Policy 28:403-410

Harris C., and D. Laibson (2001), "Dynamic choices of hyperbolic consumers", Econometrica, Vol. 69, No. 4, 935- 957.

Hartman R., M. Doane and C. K. Woo (1991), “Consumer Rationality and the Status Quo”. Quarterly Journal of Economics 106: 141-62

Harvey C.M. (1994), “The reasonableness of non-constant discount”, Journal of Public Economics 53 3151.

Hassett K.A., and G.E. Metcalf (1993), "Energy Conservation Investment: Do Consumers Discount the Future Correctly?", Energy Policy 21: 710-16.

Hassett K.A., and G.E. Metcalf (1995), "Energy Tax Credits and Residential Conservation Investment: Evidence from Panel Data" Journal of Public Economics 57: 201-17.

Hein L., and K. Blok (1995), "Transaction costs of energy efficiency improvement. In Proceedings of the 1995 ECEEE summer study.

Helfand G., and A. Wolverton (2011), "Evaluating the Consumer Response to Fuel Economy: A review of the Literature", International Review of Environmental and Resource Economics 5 (2):103-146. 
Hines J.M., Hungerford H. R. and A. N. Tomera (1987), "Analysis and Synthesis of Research on Responsible environmental Behaviour: a Meta-Analysis" Journal of Environmental Education, Vol. 18 , issue 2.

Hirst E., and M.A, Brown (1990), "Closing the efficiency gap: barriers to the efficient use of energy", Resources, Conservation and Recycling 3, 267-281.

Holcomb J., and P. Nelson. (1992), "Another Experimental Look at Individual Time Preference" Rationality and Society 4: 199-220.

Howarth, R. B., and A. H. Sanstad (1995), "Discount Rates and Energy Efficiency", Contemporary Economic Policy, 13(3), 101-109.

IEA (2011), "Technology roadmap: energy-efficient buildings: heating and cooling equipment". OECD publication.

IEA (2012), "World Energy Outlook", OECD publication.

IEA (2013), " $\mathrm{CO}_{2}$ emissions from fuel combustion highlights", IEA Statistics.

IPCC (2014), "Residential and Commercial Buildings" Mitigation. Contribution of Working Group III to the Fifth Assessment Report of the Intergovernmental Panel on Climate Change, Cambridge, UK and New York, NY, USA.: Cambridge University Press.

Jacobsen, Grant D., and M. J. Kotchen (2012), "Are Building Codes Effective at Saving Energy? Evidence from Residential Billing Data in Florida"," Review of Economics and Statistics, 95(1), 34-49.

Jaffe A, Newell R and R. Stavins (2004), “The Economics of Energy Efficiency" In Encyclopedia of Energy, ed. C Cleveland, pp. 79-90.

Jaffe A. B., and R. N. Stavins (1994a), “The energy- efficiency gap, What does it mean?", Energy Policy $22(10)$ 804-810.

Jaffe A. B., and R. N Stavins (1994b). "The energy paradox and the diffusion conservation technology", Resource and Energy Economics (16) 91-122.

Jaffe A. B., and R. N Stavins (1995), "Dynamic Incentives of Environmental Regulations: The Effects of Alternative Policy Instruments on Technology Diffusion", Journal of Environmental Economics and Management 29(3): S43-S63.

Kahneman D., and A. Tversky (1979), "Prospect Theory: An Analysis of Decision Under Risk", Econometrica 47: 263-91.

Kahneman D., and A. Tversky (1984), "Choices, Values, and Frames", American Psychologist 39, 341350.

Kallbekken S., Saelen H. and A. T. Hermansen Erlend (2012), „Bridging the Energy Efficiency Gap: A Field Experiment on Lifetime Energy Costs and Household Appliances", Journal of Consumer Policy.

Kempton W., and L. Montgomery (1982), "Folk Quantification of Energy”, Energy 7:817-27. 
Kollmuss A., and M. Agyeman (2002), "Mind the gap: why people act environmentally, and what are the barriers to pro-environmental behaviours?", Environmental Education Research 8:3, 239-260.

Larrick R., and J. Soll, (2008), “The MPG Illusion,” Science 320 (5883): 1593-94.

Levinson A., and S. Niemann (2004), "Energy Use by Apartment Tenants When Landlords Pay for Utilities", Resource and Energy Economics 26: 51-75

Martinssonn J., Lundqvist Lennart J. and A. Sundstrom (2011), "Energy saving in Swedish households. The (relative) importance of environmental attitudes", Energy Policy 39 (2011) 5182-5191.

McFadden D. (1999), “Rationality for economists?”, Journal of Risk and Uncertainty 19:73-105.

Meier A., Wright, J. and A.H. Rosenfeld (1983), "Supplying Energy through Greater Efficiency" University of California Press.

Metcalf, G.E. (1994), “Economics and rational Conservation Policy”, Energy Policy 22 (10):819-825.

Metcalf G. E., and K. A. Hassett (1999), "Measuring the Energy Savings from Home Improvement Investments: Evidence from Monthly Billing Data", Review of Economics and Statistics 81 (3):516528.

Murtishaw S., and J. Sathaye (2006), "Quantifying the Effect of the Principal-Agent Problem on US Residential Use", Lawrence Berkeley National Laboratory LBNL-59773. Berkeley, California .

Nadel S., and K. Keating (1991), "Engineering Estimates vs. Impact Evaluation Results: How Do They Compare and Why?" Research Report U915, American Council for an Energy-Efficient Economy.

National Academy of Sciences (1992), "Policy Implications of Greenhouse Warming: Mitigation, Adaptation, and the Science Base", Washington, DC: National Academy Press.

Newell, R., A. Jaffe and R. Stavins (1999), "The Induced Innovation Hypothesis and Energy-Saving Technological Change", Quarterly Journal of Economics 114 (3): 941-75.

Newell R. G. and J. Siikamaki (2014), Nudging Energy Efficiency Behavior: The Role of Information Labels, Journal of the Association of Environmental and Resource Economists 1 (4): 555-598.

O’Donoghue T., and M. Rabin (1999), “Doing it now or later”, American Economic Review 89:103-24.

Olli E., Grendstad G. and D. Wollebaek (2001), "Correlates of Environmental Behaviour: bringing back social context", Environment and Behavior 33: 181-208.

Palmer K., M. Walls, H. Gordon, and T. Gerarden (2011), “Assessing the Energy-Efficiency Information Gap: Results from a Survey of Home Energy Auditors", Resources for the future, Discussion paper RFF DP 11-42.

Palmer K., M. Walls, H. Gordon and T. Gerarden (2012), "Borrowing to Save Energy: An Assessment of Energy Efficiency Finance Programs”, RFF Report .

Raaij W., and T. Verhallen (1983), “A behavioural model of residential energy use”, Journal of Economic Psychology 3 39-63. 
Ranjan R., and J. Shogren (2006), "How probability weighting affects participation in water markets" Water Resources Research 42:262-82.

Rosenfeld A., C. Atkinson, J. Koomey, A. Meier, R. J. Mowris and L. Price (1993). "Conserved Energy Supply Curves for U.S. Buildings”, Contemporary Policy Issues, 11 (1): 45-68.

Saheb Y., A. Saussay, V. Rozite, C. Johnson and A. Blyth (2012), "Innovative Market Framework to Enable Deep Renovation of Existing Buildings in IEA Countries" 2013 International Energy Program Evaluation Conference, Chicago.

Sanstad A. H, and R.B. Howarth (1994) “"Normal' markets, imperfections and energy efficiency", Energy Policy 22 (10) 811-818.

Sanstad A. H, Blumstein C. E. Stoft Steven (1995),"How high are option values in energy-efficiency investments?", Energy Policy 23 (9): 730-743.

Sanstad A. H, M. Hanemamm and M. Auffhammer (2006), "End-use Energy Efficiency in a "PostCarbon", California Economy: Policy Issues and Research Frontiers, The California Climate Change Centre at UC Berkely, Berkeley, CA.

Schleich J., and E. Gruber (2008), "Beyond case studies: Barriers to energy efficiency in commerce and the services sector", Energy Economics 30 449-464.

Simon, H.A. (1959). Theories of Decision-Making in Economics and Behavioral Science. The American Economic Review, Vol. 49, No. 3, pp. 253-283

Shogren J., and L. Taylor (2008), "On Behavioral-Environmental Economics", Review of Environmental Economics and Policy 2: 26-44.

Sovacool B. K. (2009), "The cultural barriers to renewable energy and energy efficiency in the United States", Technology in Society 31 365-373.

Stern, P.C. and Aronson (1984), "Energy use: the human dimension. Freeman”, New York.

Stern, P. C. (1986), "Blind Spots in Policy Analysis: What Economics Doesn't Say about Energy Use", Journal of Policy Analysis and Management, 5(2), 200-227.

Sutherland, R. J. (2003), "The High Costs of Federal Energy Efficiency Standards for Residential Appliances', Policy Analysis, No 504.

Tietenberg, T. (2009), "Reflections - Energy Efficiency Policy: A Pipe Dream or a Pipeline to the Future?",Review of Environmental Economics and Policy 3 (2):304-320.

Train, K. (1985), "Discount Rates in Consumers' Energy Related Decisions: A Review of Literature", Energy (12), 1243-1253.

Tsvetanov T., and K. Segerson (2013), "Temptation as a Factor behind the Energy-Efficiency Gap: Some Empirical Evidence", University of Connecticut Working Paper.

Turrentine T., and K. Kurani (2007). Car Buyers and Fuel Economy? Energy Policy 35 (2):1213-1223 
Tversky A., and D. Kahneman (1974), "Judgment under uncertainty: heuristics and biases", Science 185, 1124-1131.

Tversky A., and D. Kahneman (1981), "The framing of decisions and the psychology of choice", Science $211,453-458$.

Van Soest D.P., and E. Bulte (2001), "Does the Energy-Efficiency Paradox Exist? Technological Progress and Uncertainty", Environmental and Resource Economics 18: 101-12.

Vogel R. C., and D.W. Adams (1997), "Costs and Benefits of Loan Guarantee Programs", The Financier 41(1-2): 22-29.

Weller C. E. (2007), "Access denied: low income and minority families face more credit constraints and higher borrowing costs", Working paper Centre for American Progress.

Wilson C., and H. Dowlatabadi (2007), "Models of decision making and residential energy use", Annual Review of Environment Resources, 32:169-203.

Wolak F. (2006), "Residential Customer Response to Real-Time Pricing: The Anaheim Critical-Peak Pricing Experiment, University of California Energy Institute Center for Study of Energy Markets, CSEM Working Paper 151, Berkeley, CA.

Yates S., and E. Aronson (1983), "A Social Psychological Perspective on Energy Conservation in Residential Buildings", American Psychologist 38: 435-44.

Zobler N, and K. Hatcher (2003), "Financing Energy Efficiency Projects", Government Finance Review February: 14-18. 


\section{WORKING PAPERS}

The full series of Economics Department Working Papers can be consulted at www.oecd.org/eco/workingpapers

1221. Recent trends in productivity in China - shift-share analysis of labour productivity growth and the evolution of the productivity gap

(May 2015) by Margit Molnar and Thomas Chalaux

1219. Providing the right skills to all in China - from "made in China" to "created in China

(May 2015) by Margit Molnar and Vincent Koen

1218. Agricultural reforms and bridging the gap for rural China

(May 2015) by Ben Westmore

1217. A snapshot of China's service sector

(May 2015) by Margit Molnar and Wei Wang

1216. Does the post-crisis weakness of global trade solely reflect weak demand?

(May 2015) by Patrice Ollivaud and Cyrille Schwellnus

1215. Estonia: raising productivity and benefitting more from openness

(May 2015) by Andreas Kappeler

1214. Estonia: making the most of human capital

(May 2015) by Andrés Fuentes Hutfilter

1213. The Czech labour market: documenting structural change and remaining challenges

(May 2015) by Sónia Araújo and Petr Malecek

1212. Reforming the Slovak public sector

(April 2015) by Lilas Demmou and Robert Price

1211. Spurring growth in lagging regions in the Slovak Republic

(April 2015) by Lilas Demmou, Gabriel Machlica and Martin Haluš

1210. Skill mismatch and public policy in OECD countries

(April 2015) by Müge Adalet McGowan and Dan Andrews

1209. Labour market mismatch and labour productivity: evidence from PIAAC data

(April 2015) by Müge Adalet McGowan and Dan Andrews

1208. Maintaining an efficient and equitable housing market in Belgium

(April 2015) by Sanne Zwart

1207. Determinants of the low female labour force participation in India

(April 2015) by Piritta Sorsa, Jan Mares, Mathilde Didier, Caio Guimaraes, Marie Rabate,

Gen Tang and Annamaria Tuske

1206. Strengthening skill use and school-to-work transitions in the Czech Republic

(April 2015) by Sónia Araújo and Petr Malecek 
1205. Reforming the tax on immovable property: taking care of the unloved (April 2015) by Hansjörg Blöchliger

1204. Taxation and investment in Colombia (April 2015) by Sarah Perret and Bert Brys

1203. Efficiency and contestability in the Colombian banking system (April 2015) by Christian Daude and Julien Pascal

1202. Fiscal decentralisation in Colombia: new evidence regarding sustainability, risk sharing and "fiscal fatigue"

(April 2015) by Guillaume Bousquet, Christian Daude and Christine de la Maisonneuve

1201. Effects of economic policies on microeconomic stability

(April 2015) by Boris Cournède, Paula Garda and Volker Ziemann

1200. The 2013 update of the OECD's database on product market regulation - policy insights for $O E C D$ and non-OECD countries (April 2015) by Isabell Koske, Isabelle Wanner, Rosamaria Bitetti and Omar Barbiero

1199. Improving taxes and transfers in Australia

(April 2015) by Philip Hemmings and Annamaria Tuske

1198. Federal-state relations in Australia

(April 2015) by Vassiliki Koutsogeorgopoulou and Annamaria Tuske

1197. Sharing the fruits of growth with all Mexicans

(April 2015) by Eduardo Olaberriá and Valéry Dugain

1196. What makes Mexicans happy?

(April 2015) by Valéry Dugain and Eduardo Olaberriá

1195. Improving the labour market integration of immigrants in Belgium (March 2015) by Álvaro Pina, Vincent Corluy and Gerlinde Verbist

1194. Raising the potential of the domestically oriented sector in Germany (March 2015) by André Eid and Andrés Hutfilter

1194. Raising the potential of the domestically oriented sector in Germany (March 2015) by André Eid and Andrés Hutfilter

1193. Improving transport infrastructure in Russia (March 2015) by Alexander Kolik, Artur Radziwill and Natalia Turdyeva

1192. Improving the business climate in Russia

(March 2015) by Arthur Radziwill and Yana Vaziakova

1191. Determinants of female entrepreneurship in India

(March 2015) by Arnaud Daymard 